\title{
Redefinition of the boundary between the Taebaeksan Basin and the Ogcheon metamorphic belt, Korea: a remark on the South Korean Tectonic Line (SKTL)
}

\author{
${ }^{1}$ Department of Earth and Environmental Sciences, Jeonbuk National University, South Korea; *Corresponding author, \\ E-mail: ocwhan@jbnu.ac.kr \\ ${ }^{2}$ School of Earth and Environmental Sciences, Seoul National University, South Korea \\ ${ }^{3}$ Scientific instrumentation \& management, Korea Basic Science Institute, South Korea \\ ${ }^{4}$ Department of Earth Sciences, Indian Institute of Technology Bombay (IITB), India
}

(Received: May 17, 2020; Revised accepted: December 19, 2020)

https://doi.org/10.18814/epiiugs/2020/020093

One of critical boundaries in Korea is the boundary between the Taebaeksan Basin and the Ogcheon metamorphic belt. We performed field mapping and geochronological/geochemical analyses in the Jecheon-Maepo areas. In the Bonghwajae section, the "Yamisan unit" (761 3 Ma) belonging to the Ogcheon Supergroup occurs eastward beyond previous limit of Ogcheon metamorphic belt. Farther east, the post-Cambrian "Soyari unit" of uncertain affinity occurs. The Soyari unit borders a typical sequence of Taebaeksan Basin to the east in Maepo. We suggest that the boundary between the Ogcheon metamorphic belt and the Taebaeksan Basin is more than $20 \mathrm{~km}$ wide zone. Occurrence of the "Danri window" shows that the Ogcheon Supergroup sequence overlies the Joseon Supergroup unit along a decollement in the Jecheon-Maepo areas. The decollements and $N W$ - to $N N W$-trending structures resulted from $N E$ - or ENE-directed shortening probably during the Songrim Orogeny (Indosinian). We consider two alternative models for the origin/structural relationship between the Taebaeksan Basin and the Ogcheon metamorphic belt. In one plate model, the Taebaeksan Basin had formed close to the Ogcheon metamorphic belt. In two plate model, the Taebaeksan Basin had formed in the North China Block, and was transported hundreds kilometers southward along a continental transform fault.

\section{Introduction}

In Korea, the Ogcheon Belt (or Okcheon) is a composite orogenic belt consisting of two contrasting domains (Fig. 1). The Ogcheon metamorphic belt is an orogenic belt resulting from closure of an aborted rift by intracontinental orogeny during the Paleozoic (Cluzel et al., 1991; Cho and Kim, 2005; Cheong et al., 2003; Kim et al., 2007). The Tae- baeksan Basin is an unmetamorphosed or weakly-metamorphosed Paleozoic sedimentary basin bordering the Ogcheon metamorphic belt to the southwest (Fig. 1). However, the nature of boundary between Taebaeksan Basin and Ogcheon metamorphic belt is still ambiguous. The boundary should be either local or inter-plate depending on different tectonic models (Chough et al., 2000; Kim et al., 2001; Ree et al., 2001; Lee and Lee, 2003; Oh and Kusky, 2007). The ambiguity of boundary nature means that no tectonic model has been really substantiated. In reverse, however, clarifying the nature of boundary between the Taebaeksan Basin and the Ogcheon metamorphic belt may provide a key to establish correct tectonic model.

Rock units around current boundary between the Taebaeksan Basin and the Ogcheon metamorphic belt have been identified incorrectly because of three interrelated reasons. One is that ages of the sequences around the boundary are mostly unknown. The second is that metavolcanic rocks occurring in the boundary region have not been recognized. The third reason is that most researchers have been unaware of the significance of distinguishing metacarbonate from carbonate rocks in the boundary region. No matter metamorphosed or not, any calcitic or dolomitic unit in this region has been correlated to the CambrianOrdovician Joseon Supergroup sequence in the Taebaeksan Basin (Lee and Park, 1965; Son, 1970; Reedman et al., 1973; Kim and Kim, 1974; Kihm et al., 1996; Ree et al., 2001; Kim et al., 2018). These authors have placed the Taebaeksan Basin-Ogcheon metamorphic belt boundary along the western margin of carbonate or metacarbonate units. Nearly all studies have accepted such correlations for a long time. However, our mapping and zircon dating in the Jecheon-Maepo areas reveal that the metacarbonate and carbonate rocks belong to separate units marked by different ages and/or lithology. This shows that the boundary between the Taebaeksan Basin and the Ogcheon metamorphic belt has been misunderstood.

To resolve problems described above, we attempt to redefine the boundary between the Taebaeksan Basin and the Ogcheon metamorphic belt, based on field mapping and zircon dating as well as geochemical analysis in the Jecheon-Maepo areas. The "Danri window" 

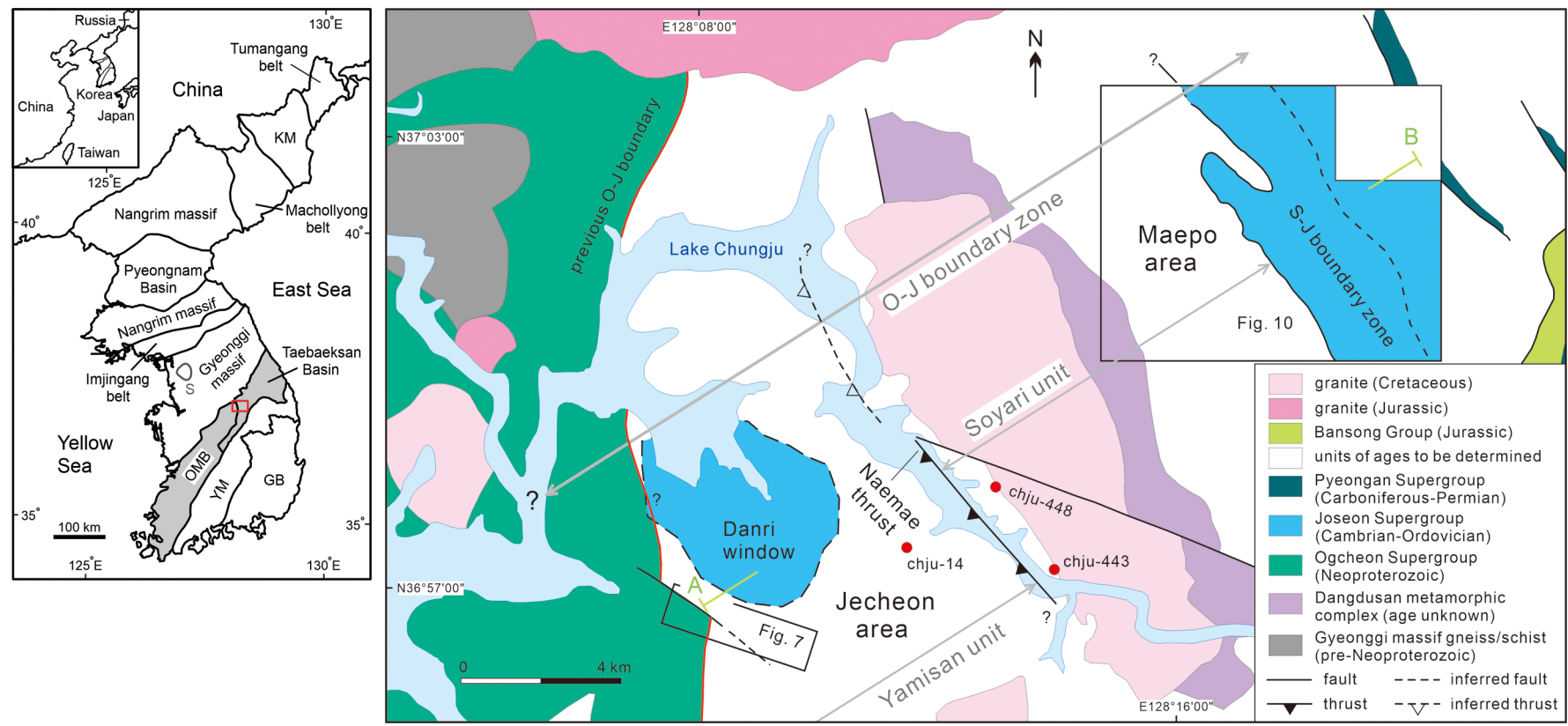

Figure 1. (Left) Distribution of massifs and orogenic belts in Korea. Gray zone is the Ogcheon Belt comprising the Ogcheon metamorphic belt (OMB) and the Taebaeksan Basin. Red box indicates location of the Jecheon-Maepo areas. (Right) Geologic map of the Jecheon-Maepo areas. Red dots indicate location of analyzed samples. Compiled from Hwang et al. (1996), Koh et al. (2001), Kihm and Kim (2003), and Lim and Choi (unpubl. data). GB: Gyeongsang Basin, KM: Kwanmo massif, YM: Yeongnam massif, S: Seoul.

found in the Jecheon area suggests existence of a decollement, which further necessitates the redefinition. Two alternative models are considered regarding the nature of boundary between the Taebaeksan Basin and the Ogcheon metamorphic belt.

\section{Geologic Setting}

The Korean Peninsula consists of Proterozoic massifs separated by a number of orogenic belts (Fig. 1). The Ogcheon Belt comprises the Taebaeksan Basin and the Ogcheon metamorphic belt (Fig. 1). The Taebaeksan Basin contains shallow marine carbonate successions which intercalate some siliciclastics and were deposited during the Cambrian to Middle Ordovician (Joseon Supergroup) (Chough et al., 2000; Choi, 2019a). The Taebaeksan Basin also contains thick sedimentary successions of marginal marine to non-marine facies (Pyeongan Supergroup), deposited unconformably on the Joseon Supergroup sequences during the Pennsylvanian to Early Triassic(?) (Chough et al., 2000). In the Taebaeksan Basin, the Joseon and Pyeongan Supergroup sequences are unconformably overlain by non-marine clastic deposits of late Early Jurassic age (Bansong Group) (Kim and Koh, 1992; Han et al., 2006). The Ogcheon metamorphic belt consists of low- to medium-grade metapelite/metapsammite, quartzite, metadiamictite, marble and metavolcanic rocks deposited during the Neoproterozoic to Paleozoic (Ogcheon Supergroup) (Chough et al., 2000; Cho and Kim, 2005; Lim et al., 2005; Choi et al., 2012). The Ogcheon metamorphic belt formed by closure of an aborted rift basin due to NW-SE shortening during a Paleozoic intracontinental orogeny (Ogcheon orogeny) (Cluzel et al., 1991; Chough et al., 2000; Cho and Kim, 2002, 2005; Cheong et al., 2003; Kim et al., 2007).

In the Jecheon area, Neoproterozoic sequence of the Ogcheon Super- group dominantly occurs, consisting of marble, bimodal volcanic suite, phyllite, quartzite and amphibolite. The sequence of Joseon Supergroup also occurs in the "Danri window" (Fig. 1) where carbonate rocks, little deformed and occasionally containing brachiopod and crinoid fossils, are exposed (Lim and Choi, unpubl. data). The carbonate rocks possibly range from Ordovician to Silurian in age based on newly found fossils including echinoderm, crinoid, and trilobite (Lee, 2020).

\section{Geochronology and Geochemistry}

Zircons separated from metavolcanic rocks, phyllites and amphibolite were dated using laser ablation MC-ICP-MS at Korea Basic Science Institute in Korea and laser ablation ICP-MS at Wuhan SampleSolution Analytical Technology in China, and using Sensitive High-resolution Ion Microprobe (SHRIMP) at Hiroshima University in Japan. Major and trace elements of metavolcanic rocks and amphibolite were analyzed at Actlabs in Canada and at Korea Basic Science Institute in Korea. Detailed descriptions of sample preparation and analytical procedures can be found in Supplementary data 1, and data tables in Supplementary data 2.

To the west of Lake Chungju, a metavolcanic rock shows features of lava flow such as flow bands and flow folds (Fig. 2a). This metavolcanic rock (chju-120) yielded zircons showing Neoproterozoic or older ages (Fig. 3a). A concordia age of $761 \pm 3$ Ma coinciding with the strong peak in the probability density diagram is suggested to be the eruption age (Fig. 4a). Other older peaks represent ages of detrital zircons probably derived from lithic fragments. An amphibolite (chju-99) gives a concordia age of $762 \pm 24 \mathrm{Ma}$ (Fig. 4b), suggested to be intrusion age.

To the east of Lake Chungju, two metasedimentary rocks (phyllite) (chju-443, 448) and one metarhyolite (gss 5-2) yielded zircons mostly 

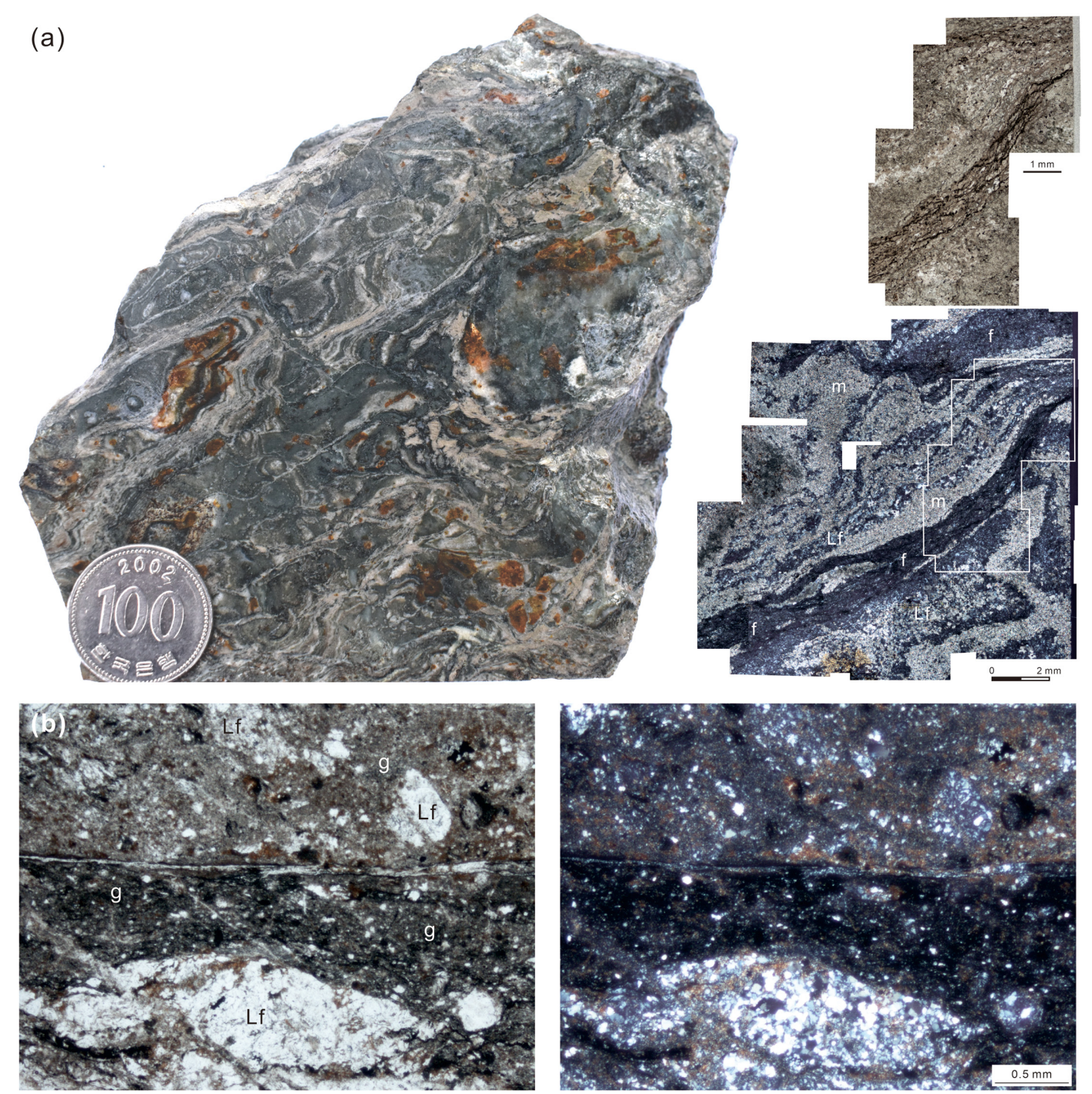
Lf: lithic fragment
$\mathrm{m}$ : mafic layer altered into amphibole and calcite g: groundmass
f: felsic layer

Figure 2. (a) A rock slab and mosaics of photomicrographs showing a lava flow (basaltic trachy-andesite; chju-120). Thin section was cut several mm below the rock slab surface. Top right: plane-polarized light view of white box. Bottom right: cross-polarized light view. The coin is $2.4 \mathrm{~cm}$ in diameter. (b) Photomicrographs of a lithic tuff (rhyolite; gss 5-2). Left: plane-polarized light view. Right: cross-polarized light view.

of Cambrian or older ages (Fig. 3b). Maximum depositional ages of two phyllites (chju-443, 448) are $480 \pm 6 \mathrm{Ma}$ and $501 \pm 6 \mathrm{Ma}$, respectively, based on youngest single grain ages (Coutts et al., 2019) (Figs. $3 \mathrm{~b}$ and 5). The metarhyolite is a lithic tuff (Fig. 2b). This sample (gss 5-2) gave mostly detrital zircons with rounded shape probably derived from lithic fragments and possibly unconsolidated sediments blown out as part of pyroclastics during eruption. A few angular zircons of uncertain origin exist, but no strong peak suggestive of volcanism was found (Figs. $3 b$ and 5). We, therefore, treated the zircon data of metarhyolite (gss 5-2) in the same way as those of sedimentary rocks. The maximum depositional age of metarhyolite (gss 5-2) is $489 \pm 6 \mathrm{Ma}$, based on youngest single grain ages (Coutts et al., 2019) (Figs. 3b and 5).

Based on above results, the depositional ages of two phyllites and metarhyolite occurring east of Lake Chungju are constrained to be Ordovician or younger. It should be noted that one of small number of zircons separated from other phyllites in east of Lake Chungju yielded a date as young as $382 \pm 4 \mathrm{Ma}$ (gss-34 in Fig. $3 \mathrm{~b}$ and Table S1). Thus, it is a possibility in this area that all phyllites and metavolcanic rocks are much younger than the Ordovician or, alternatively, some phyllites are much younger than other phyllites and metavolcanic rocks.

To the west of Lake Chungju, metavolcanic rocks and an amphibolite coincide with basalt in composition (Fig. 6a). A metavolcanic rock (chju-120) is plotted as basaltic trachy-andesite (Fig. 6a). To the east of Lake Chungju, one metavolcanic rock (gss-14) coincides with basaltic andesite and the other (gss 5-2) with rhyolite in composition (Fig. 6a). The metavolcanic rocks and amphibolite in the area west of Lake Chungju give Ce* values of $0.88-1.05$ and metavolcanic rocks east of Lake Chungju give $\mathrm{Ce} *$ values of 1.05-1.10 (Table S3). Considering that $0.9<\mathrm{Ce} *<1.1$ is immobile range, the effects of metamorphism were negligible $\left(\mathrm{Ce} *=\mathrm{Ce}_{\mathrm{N}} / \mathrm{sqrt}\left(\mathrm{La}_{\mathrm{N}} \times \mathrm{Pr}_{\mathrm{N}}\right)\right)$. The low losses on ignition (2.34-3.67) and similar REE patterns also support the negligible effect of metamorphism (Tables S2 and S3). In the Zr vs. Y diagram, 
(a) Zircons from a metavolcanic rock (chju-120), west of Lake Chungju (Yamisan unit)

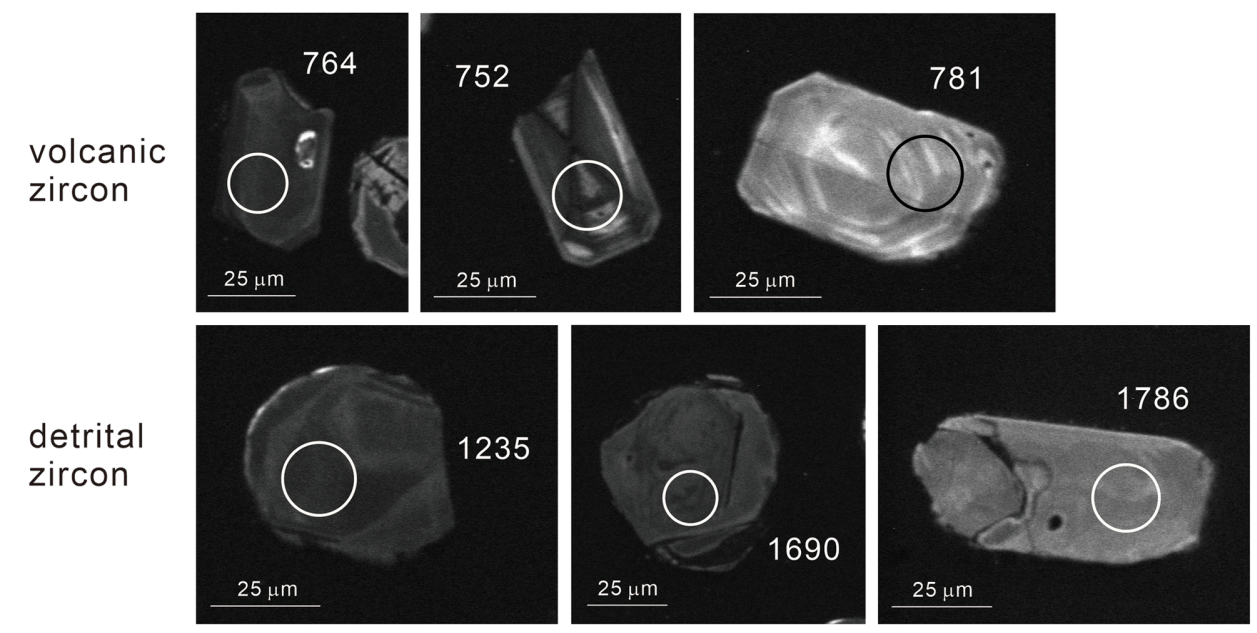

(b) Youngest zircons from phyllites and a metarhyolite, east of Lake Chungju (Soyari unit)

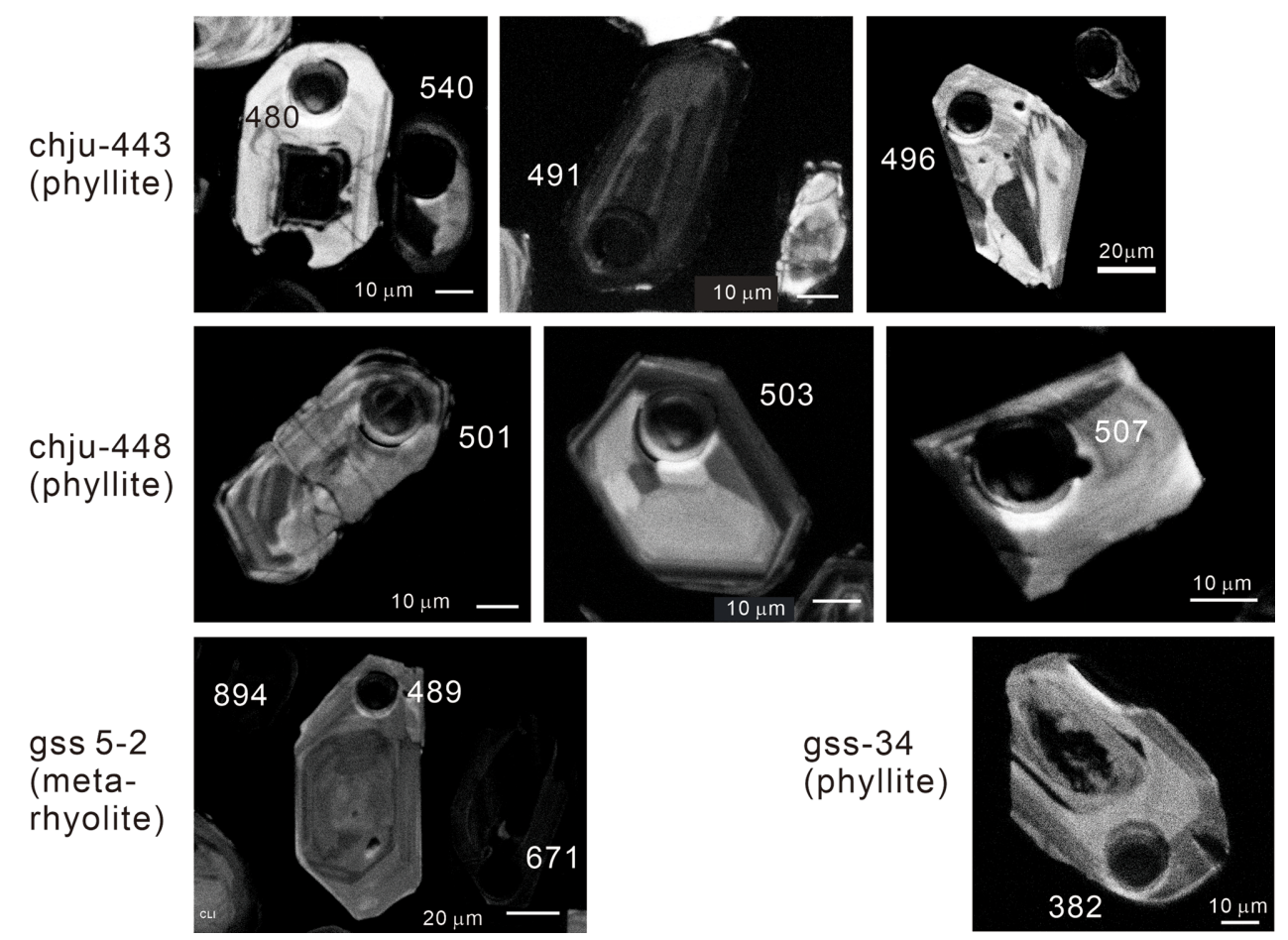

Figure 3. Cathodoluminescence images of analyzed zircon crystals and ages (Ma) obtained from each spot.

metavolcanic rocks and amphibolite are plotted in the Within Plate Basalts field (Fig. 6b). Metavolcanic rocks in the Munjuri Formation of the Ogcheon Supergroup gave similar results (Lee et al., 1998) (Fig. 6b).

\section{Misunderstanding of the Bonghwajae Section regarding the Lithology and Terrane Boundary}

The Bonghwajae section has been noticed since 1960's, assumed to be a transect running across the boundary between Ogcheon meta- morphic belt and Taebaeksan Basin. This is, however, based on incorrect correlation of the marble-metavolcanics-phyllite sequence (east of $X$ in Fig. 7) with the Joseon Supergroup (Lee and Park, 1965; Son, 1970; Reedman et al., 1973; Kim and Kim, 1974; Kihm et al., 1996; Kim et al., 2018). This correlation has brought serious debates about whether the sequence around $\mathrm{X}$ was overturned or not, and whether the contact $\mathrm{X}$ is depositional or a fault. These two were a critical issue for previous workers who believed that the "Cambrian-Ordovician Joseon Supergroup" in the Bonghwajae section can constrain the age of Ogcheon Supergroup which barely yields any fossils (Son, 1970; Reedman et al., 1973; Kim and Kim, 1974; Kihm et al., 1996). Despite 

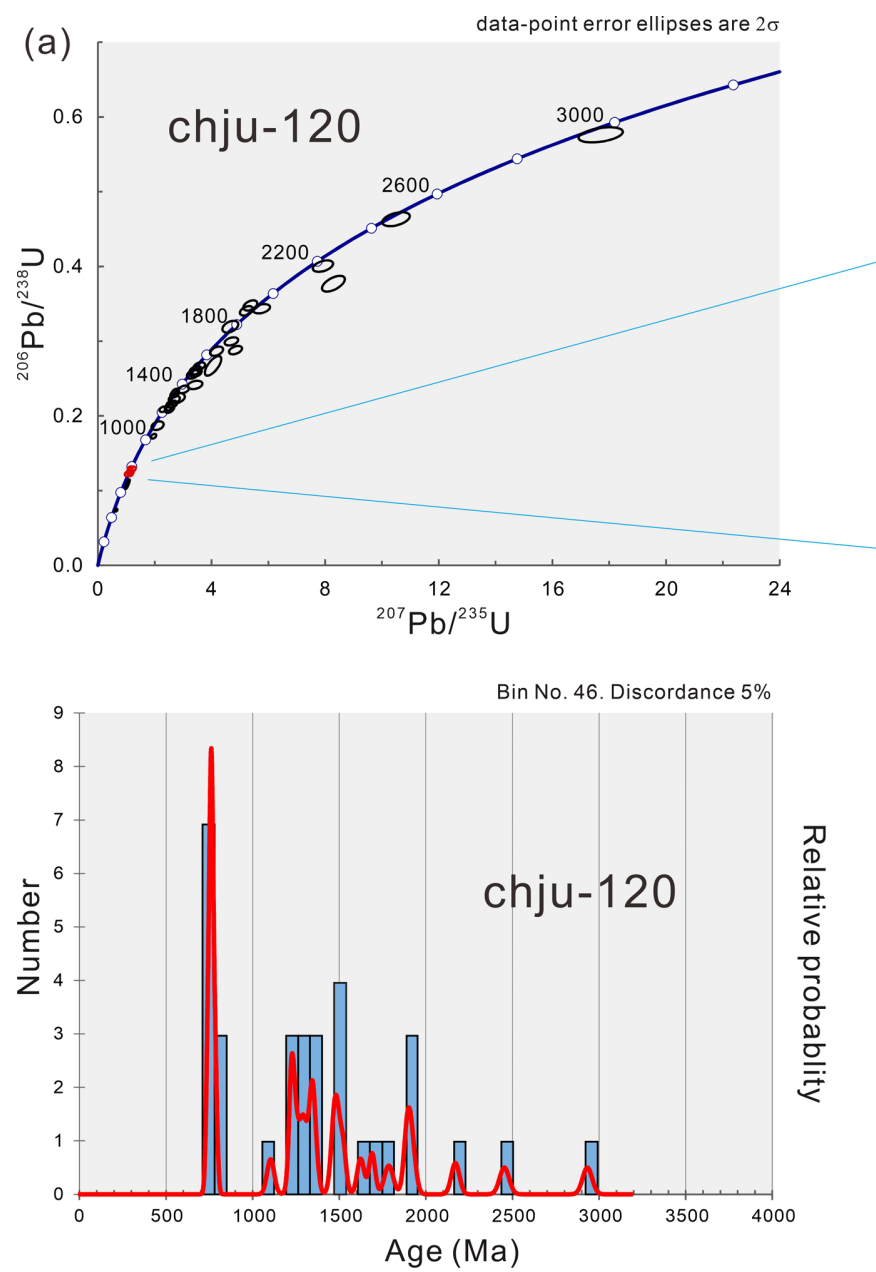
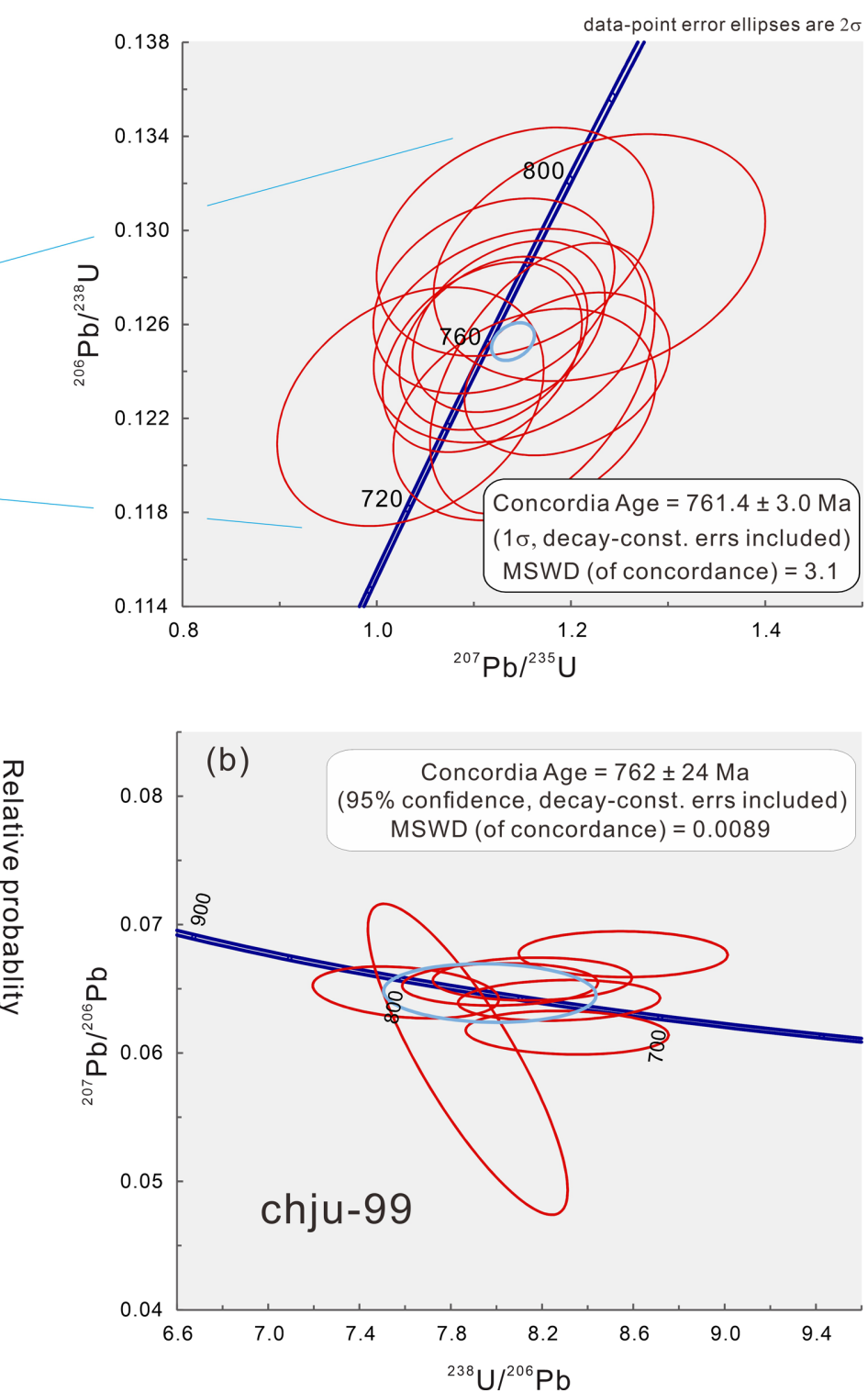

Figure 4. (a) U-Pb concordia diagram and probability density diagram of a metavolcanic rock (chju-120). (b) U-Pb concordia diagram of an amphibolite (chju-99). See Figure 7 for location.

many efforts, however, no fossils have been found in the marbles of Bonghwajae section, either (Kihm et al., 1996). However, it needs to note that there was a small number of researchers who placed the eastern boundary of Ogcheon Supergroup farther east of the Bonghwajae section (Cluzel et al., 1991).

The correlation of sequence east of $X$ with the Joseon Supergroup was solely based on lithology, but the lithology itself has been misunderstood. Our results show that the "limestone and dolomite" in the Bonghwajae section (Lee and Park, 1965; Kim and Kim, 1974; Kihm et al., 1996) are marbles containing talc (Fig. 8a). This and muscovite + chlorite assemblage in adjacent pelitic rock suggest that the Bonghwajae section sequence (east and west of X) underwent lower greenschist facies metamorphism (Fig. 8b). Lee and Park (1965) mapped a calcsilicate rock unit (their "limesilicate") as a part of the Joseon Supergroup sequence in the Hwanggang-ni Quadrangle (1:50,000 scale) which includes the Jecheon area. They explained that the calcsilicate rocks resulted from contact metamorphism caused by intrusion of a Creta- ceous granite. However, they seem to have misidentified metavolcanic rock because such calcsilicate rock unit does not exist (Lim and Choi, unpubl. data). The sample chju-120 was obtained from their calcsilicate rock unit but it is turned out to be a metavolcanic rock (Fig. 2a).

Fig. 7 shows that the sequence to the east of $X$ comprises marble, metavolcanic rock and phyllite. Presence of metavolcanic rocks shows that the sequence to the east of $\mathrm{X}$ is not a part of the Joseon Supergroup, because volcanic rock is absent in the Joseon Supergroup (Choi, 1998a, 2019a; Chough et al., 2000). A metavolcanic rock (chju-120) gives zircon U-Pb age of $761 \pm 3 \mathrm{Ma}$ (Fig. 4a). Thus, the sequence occurring east of X should be a part of the Neoproterozoic Ogcheon Supergroup, and is referred to as the "Yamisan unit" in this study. In a tectonic setting diagram, metabasalts from the Yamisan unit are plotted inside or near the Within Plate Basalts (Fig. 6b). This is consistent with previous results from the Ogcheon Supergroup (Lee et al., 1998; Kim et al., 2006).

The Yamisan unit, consisting of marble, phyllite and metavolcanic 

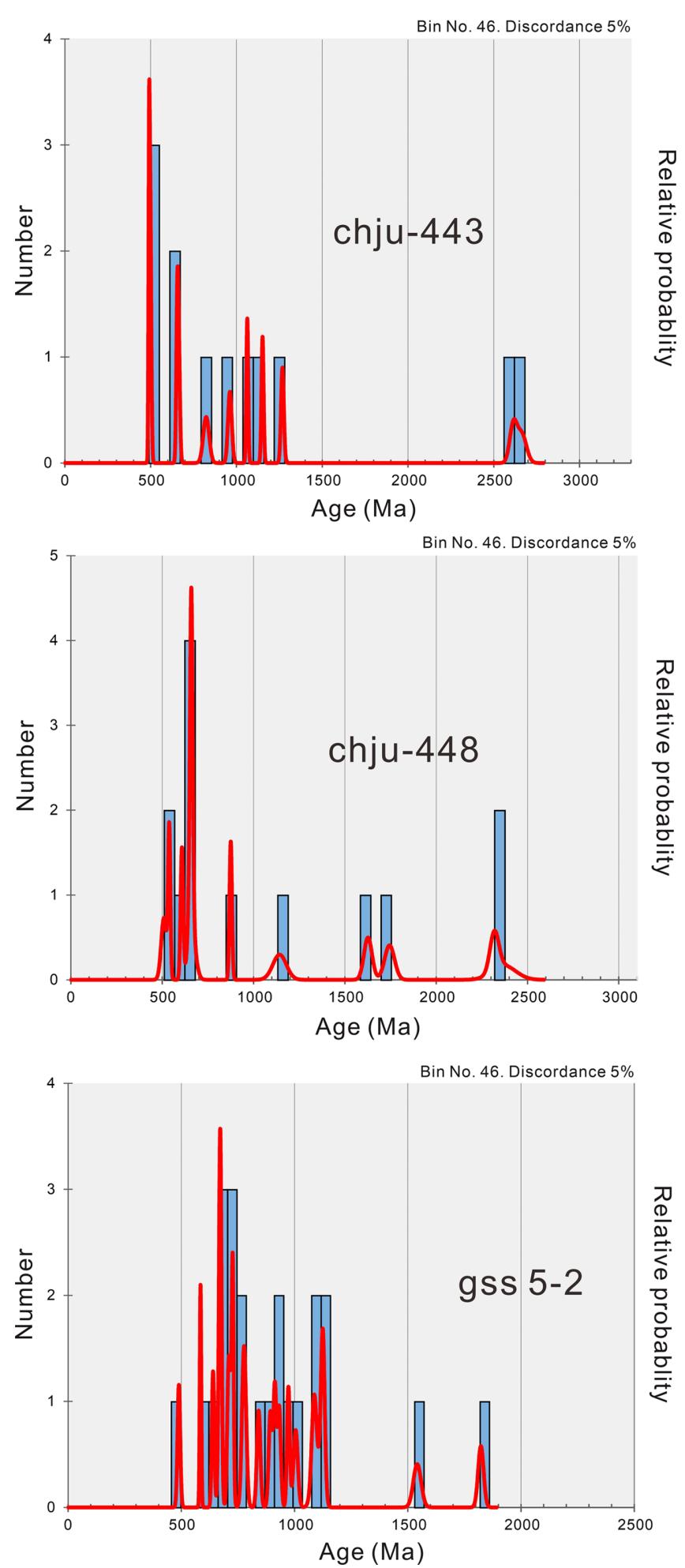

Figure 5. Probability density diagrams of $U-P b$ ages for two phyllites (chju-443, 448) and a metarhyolite (gss 5-2). See Figures 1 and 10 for location.

rock, differs from other formations of the Ogcheon Supergroup in lithology, but we do correlate the Yamisan unit to the Munjuri Formation based on the 761 Ma age of metavolcanic rock. The Munjuri Formation consists of metavolcanic rock and phyllite/schist (Fig. 9) (Choi et al., 2012). The different lithology between those two coeval units might be related to different depositional settings. On the other hand, the sequence to the west of $\mathrm{X}$ in the Bonghwajae section, consisting of metasandstone, phyllite, quartzite, amphibolite and metavolcanic rock, is more close to the Chungju Group sequence in lithology than the Hwanggangni Formation which is a metadiamictite (Fig. 9). This correlation suggests that the section around $\mathrm{X}$ is overturned, because the Yamisan unit is overlain by the Chungju Group sequence (Fig. 7). All above results demonstrate that the contact $\mathrm{X}$ is not the boundary between the Ogcheon metamorphic belt and Taebaeksan Basin. The boundary between two domains should be found farther east, as discussed below.

\section{Distinguishing Features of the "Soyari Unit"}

The Yamisan unit was thrust eastward along the "Naemae thrust" located beneath Lake Chungju (Fig. 1). Across the lake, a younger unit mostly consisting of marbles intercalating minor phyllites and metavolcanic rocks occurs. Two phyllites (chju-443, 448) near the lake give maximum depositional ages of $479 \pm 6 \mathrm{Ma}$ and $500 \pm 6 \mathrm{Ma}$, respectively (Fig. 5). In the Maepo area, a lithic tuff (Fig. 2b) having a composition of rhyolite yielded exclusively detrital zircons which give maximum depositional age of $487 \pm 6$ Ma (gss 5-2 in Fig. 5). Thus, the intercalations of marble, phyllite and metavolcanic rock are suggested to have been deposited after the Cambrian, and are referred to as the "Soyari unit" in this study (Fig. 1). The Soyari unit is younger than the Yamisan unit and bears lesser metavolcanic rocks. The Soyari unit is distinguished from the Joseon Supergroup by presence of metavolcanic rocks.

\section{Field Criteria to Identify the Soyari Unit}

The Soyari unit can be readily identified where metavolcanic rocks or phyllites are exposed east of Lake Chungju. Majority of outcrops, however, contain only marbles not easily distinguished from limestone or dolomite of the Joseon Supergroup. This is because low- to mediumgrade marbles contain little metamorphic minerals if they originally lack $\mathrm{SiO}_{2}$ (Winter, 2010). We used three criteria to distinguish the metacarbonate rocks from the carbonate rocks. First, calcitic marbles in the Soyari unit are more thinly bedded than limestones in the Joseon Supergroup. This difference is generally clear. The limestones in the Joseon Supergroup occasionally look massive. The different bedding styles may be related to different sedimentation rates, and hence to different depositional settings. Second, in addition to typical dark gray color, light gray to white colors are much more common in calcitic marbles of the Soyari unit than in limestones of the Joseon Supergroup. Dolomitic marbles and dolomites are indistinguishable in terms of bedding style and color. Third, weathering color provides a reliable criterion. In the Maepo area, weathered surfaces of limestones and dolomites in the Joseon Supergroup commonly show greenish to dark greenish colors. By contrast, the greenish weathering colors are nearly absent in calcitic or dolomitic marbles of the Soyari unit.

\section{Eastern Boundary of the Soyari Unit}

The Soyari unit borders the Joseon Supergroup along the "Campground thrust" in the Maepo area (Figs. 10 and 11). To the east of this 

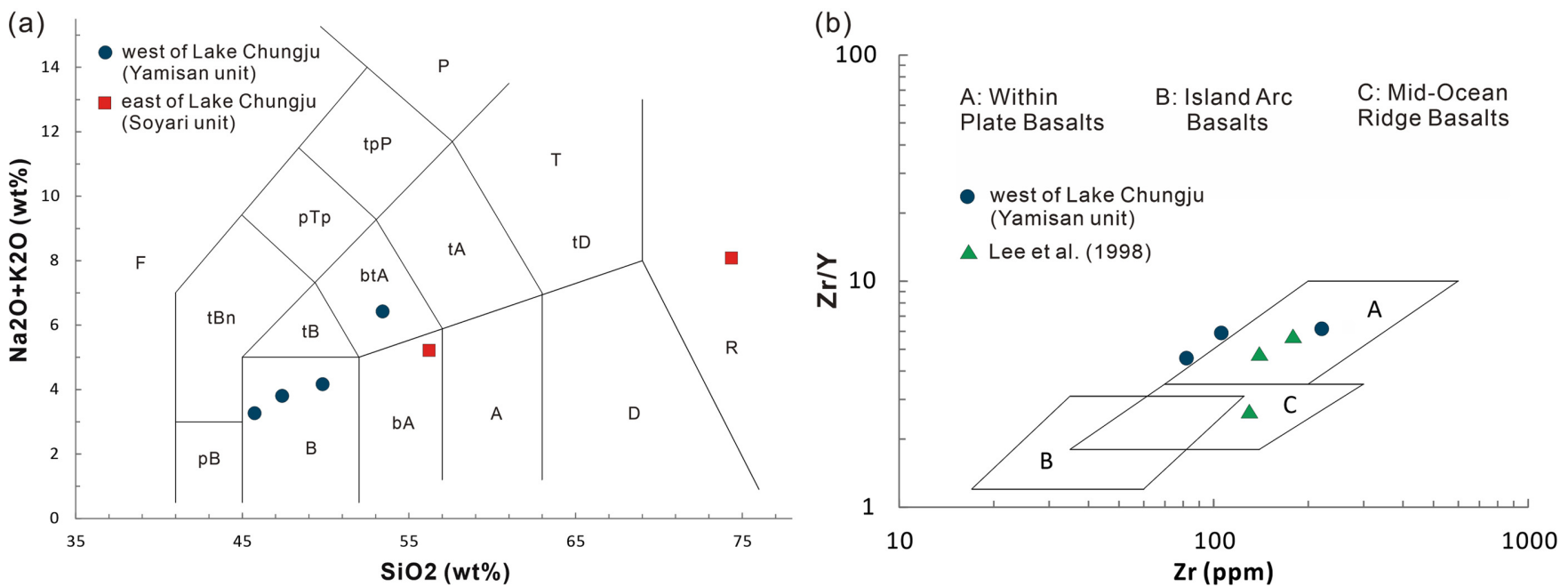

Figure 6. (a) Classification of metavolcanic rocks and an amphibolite from the Jecheon-Maepo areas. (b) Tectonic setting diagram for metavolcanic rocks and an amphibolite compared with metavolcanic rocks of the Ogcheon Supergroup (Lee et al., 1998). B: basalt, tB: trachybasalt, bA: basaltic andesite, btA: basaltic trachyandesite, A: andesite, tA: trachyandesite, D: dacite, tD: trachydacite, T: trachyte, R: rhyolite, pB: picrobasalt, tBn: tephrite basanite, pTp: phonotephrite, tpP: tephriphonolite, P: phonolite, F: foidite.

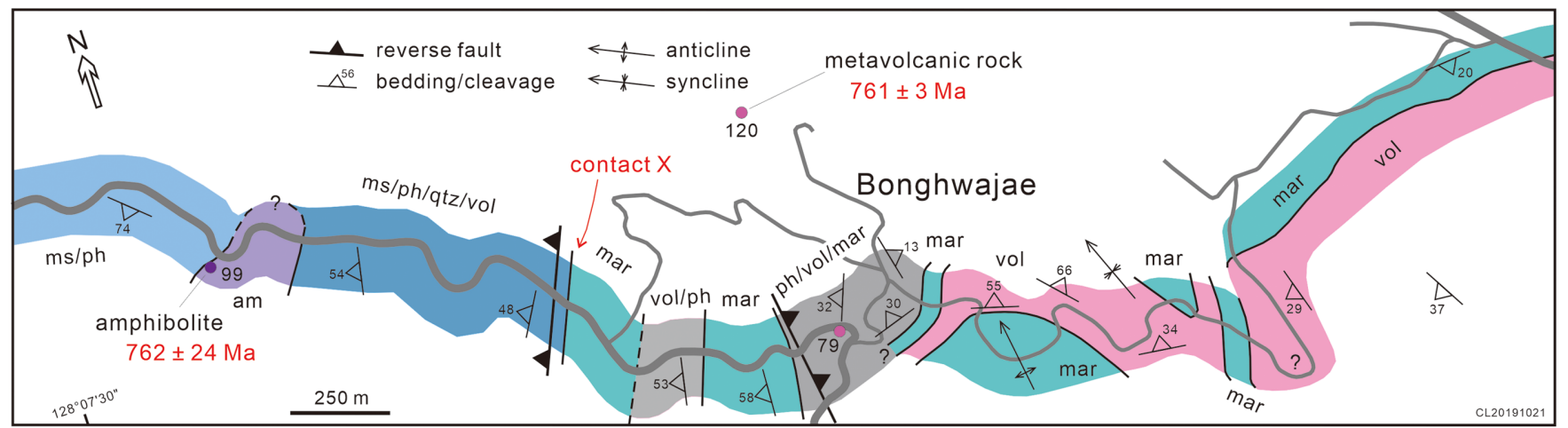

ms: metasandstone, ph: phyllite, qtz: quartzite, mar: marble, vol: metavolcanic rock

Figure 7. Route map of the Bonghwajae section.
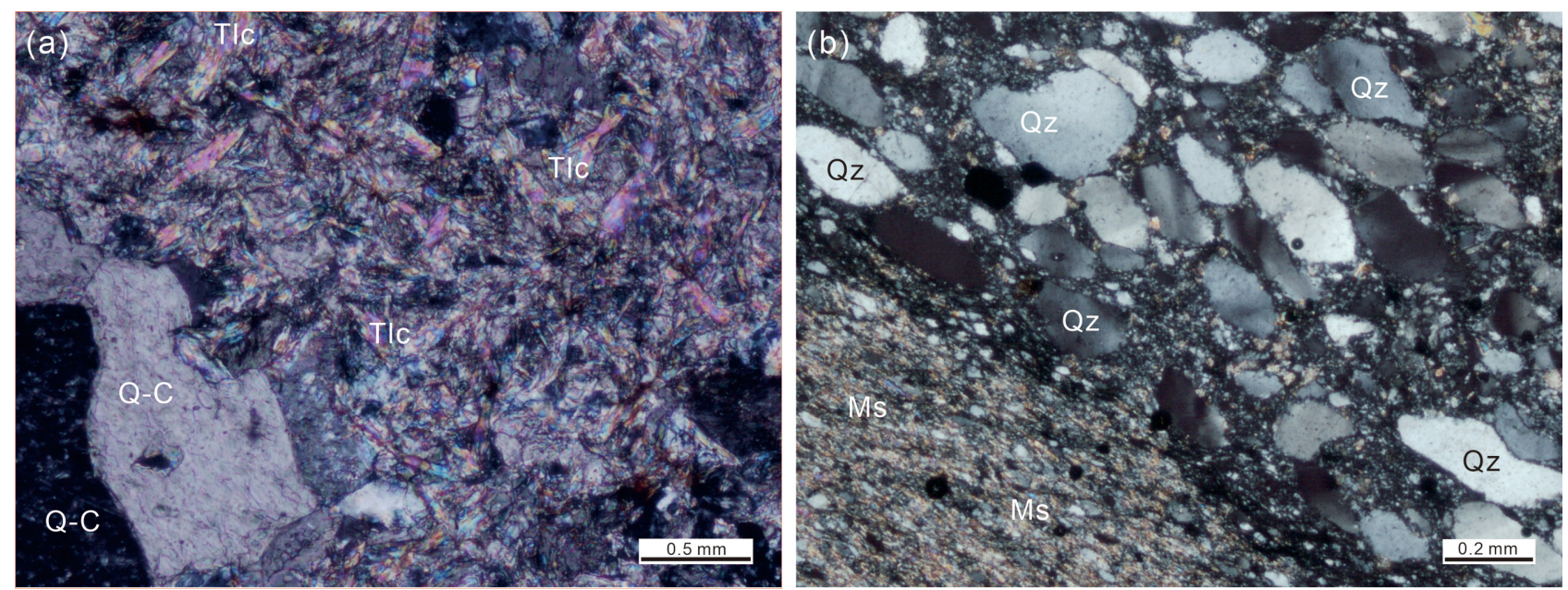

Figure 8. (a) Photomicrograph of a marble. Tlc: talc, Q-C: quartz grain replaced by calcite. (b) Photomicrograph of a metasandstone intercalating pelitic layers. Ms: muscovite, $Q z$ : quartz. Chlorite is not visible at this scale. Both (a) and (b) occur near the contact $X$.

fault, limestones and dolomites of Joseon Supergroup occur, bearing latest Cambrian trilobites at approximately $10 \mathrm{~km}$ northeast of the fault (Sohn and Choi, 2002). Early Ordovician trilobites were also found at approximately $460 \mathrm{~m}$ north of the northern margin of "S-J boundary zone" (see below) (Choi, 1998b). Small windows mapped west of the fault suggest that the Soyari unit sequence was thrust northeast- 


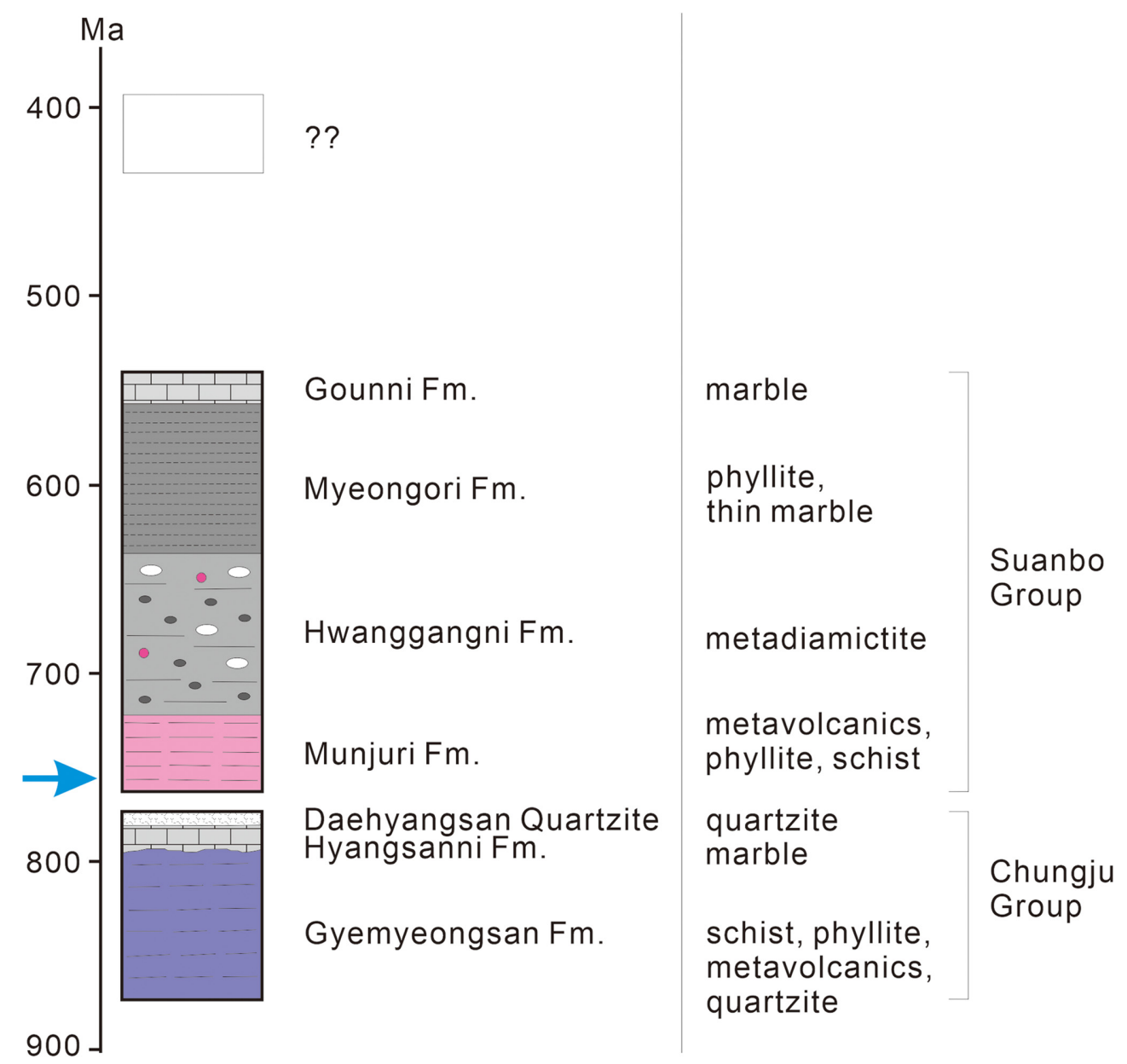

Figure 9. Stratigraphy of the Ogcheon Supergroup (modified after Choi et al., 2012). An arrow indicates approximate position of analyzed metavolcanic rock (chju-120). Age of metavolcanic rock suggests correlation of the Yamisan unit with the Munjuri Formation. The Paleozoic section of stratigraphy is partially understood. Age of Daehyangsan Quartzite is controversial. The Daehyangsan Quartzite was suggested to be younger than the early Silurian (e.g., Park et al., 2011).

ward onto the carbonate rocks of Joseon Supergroup (Fig. 10). Sinuous trace of the fault is due to a NW-plunging anticline-syncline pair that folded isoclinally the fault surface itself along with the footwall and hanging wall (Figs. 10 and 11). This suggests that the thrust was locked at some point and further shortening was accommodated by folding. Such large-scale folding is supported by mesoscopic folds and crenulation lineation which are probably minor folds associated with it (Fig. 12).

In the Maepo area, most cleavages are parallel to bedding planes. In a zone around the folded fault, referred to as the "S-J boundary zone", the bedding/cleavage in both Soyari unit and Joseon Supergroup mostly dip vertically or very steeply (Fig. 13). West of the S-J boundary zone, by contrast, the bedding/cleavage in Soyari unit and Dangdusan metamorphic complex mostly dips west at low to very steep angles (Fig. 13). This suggests that the shortening was dominantly absorbed along the S-J boundary zone by early thrusting and later steepening/ folding of the Soyari unit and Joseon Supergroup sequences due to continued northeastward push (Fig. 11). Interestingly, location of the S-J boundary zone approximately coincides with that of the eastern limit of "Ogcheon Supergroup" proposed by Cluzel et al. (1991). Cluzel et al.'s (1991) work is remarkable in that they suggested 30 years ago existence of the boundary between Ogcheon and Joseon Supergroups far east of the Bonghwajae section, although they failed to recognize our Soyari unit probably due to less developed geochronology at that time.

\section{Discussion}

We obtained striking results regarding two points. First, the boundary between the Taebaeksan Basin and the Ogcheon metamorphic belt turned out to be a wide zone, not a single contact as traditionally thought. Second, no major strike-slip fault was found between exposures of the Joseon Supergroup and the Ogcheon Supergroup sequences. This contradicts the belief of many workers (including the authors, C. Lim and D. K. Choi) that two sequences had formed in different terranes and one of the terranes (Taebaeksan Basin) bearing the Joseon Supergroup sequence migrated close to current location along a continental transform fault referred to as the South Korean Tectonic Line (SKTL; Chough et al., 2000). The two points in our results are discussed below. 


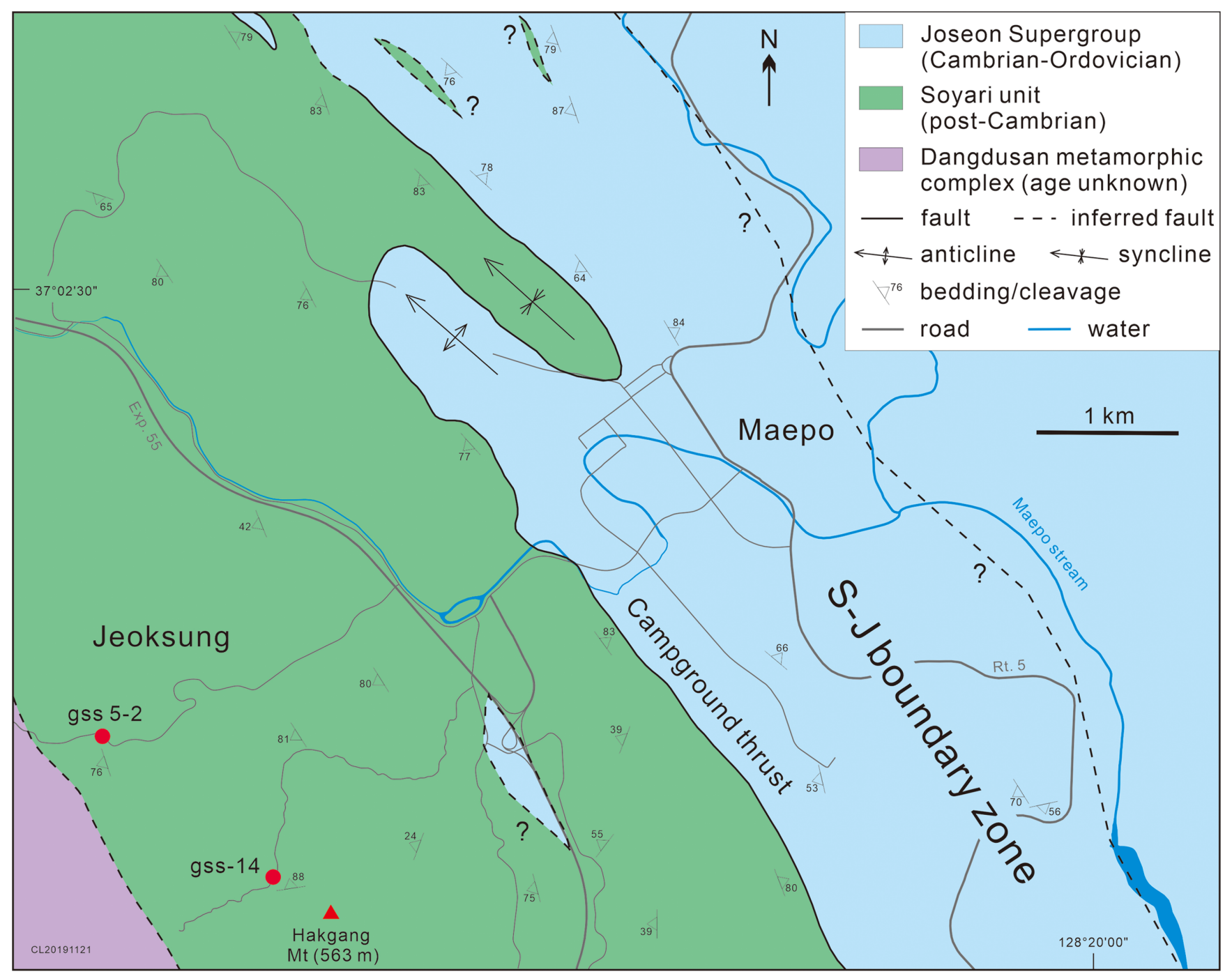

Figure 10. Geologic map of the Maepo area. Red dots indicate location of metavolcanic rocks analyzed to determine age and/or whole rock composition.

\section{Location and Structure of the Boundary between the Taebaeksan Basin and the Ogcheon Metamorphic Belt}

It has long been suggested that the Ogcheon metamorphic belt borders the Taebaeksan Basin along a single contact running across the Bonghwajae section (Lee and Park, 1965; Kim and Kim, 1974; Kihm et al., 1996; Ree et al., 2001; Kim et al., 2018). However, metavolcanic rocks do occur within the sequence east of the contact X (Fig. 7), inconsistent with the eastern sequence being a part of the Taebaeksan Basin. Zircon age of the metavolcanic rock shows that the sequence east of X (Yamisan unit) belongs to the Ogcheon Supergroup (Fig. 4a). The Yamisan unit continues eastward to the shore of Lake Chungju (Fig. 1). Thus, the easternmost exposure of Ogcheon metamorphic belt is located along the shore of Lake Chungju, not along the contact $\mathrm{X}$ in Bonghwajae section. Moreover, it should be pointed out that no evidence for intense shearing expected along tectonic boundary has been found around the contact X. Kim et al. (2018) envisaged that the layering around contact $\mathrm{X}$ resulted from transposition caused by intense shearing. However, the layering should be regarded as bedding and phyllitic cleavage parallel to each other because mesoscopic and microscopic observations around the contact $\mathrm{X}$ do not support such intense deformation (Figs. 7 and 8b). Only a small reverse fault occurs near the contact X. The "central Ogcheon thrust" of Ree et al. (2001) is unlikely to exist.

Our results show that the boundary between the Taebaeksan Basin and the Ogcheon metamorphic belt (O-J boundary zone) is a more than $20 \mathrm{~km}$ wide zone where west-dipping sequences of the Ogcheon/ Joseon Supergroups and the Soyari unit are exposed (Fig. 1). The existence of Danri window suggests that the Yamisan unit overlies the carbonate rocks of Joseon Supergroup along a decollement ("Danri thrust"; Figs. 1 and 11). The western limit of O-J boundary zone may exist below the surface, and its location is not determined yet. The Danri thrust is probably truncated by or merge with the Naemae thrust at shallow depth (Fig. 11). This is the reason why the Joseon Supergroup in the Danri window does not re-emerge along the eastern shore of Lake Chungju (Figs. 1 and 11).

The Naemae thrust strikes northwest, and other faults and lithologic boundaries as well as bedding/cleavage to the east mostly strike NW to NNW (Figs. 1, 10 and 13a). Stretching lineation is very rare and no mineral lineation has been found. It also should be noted that 


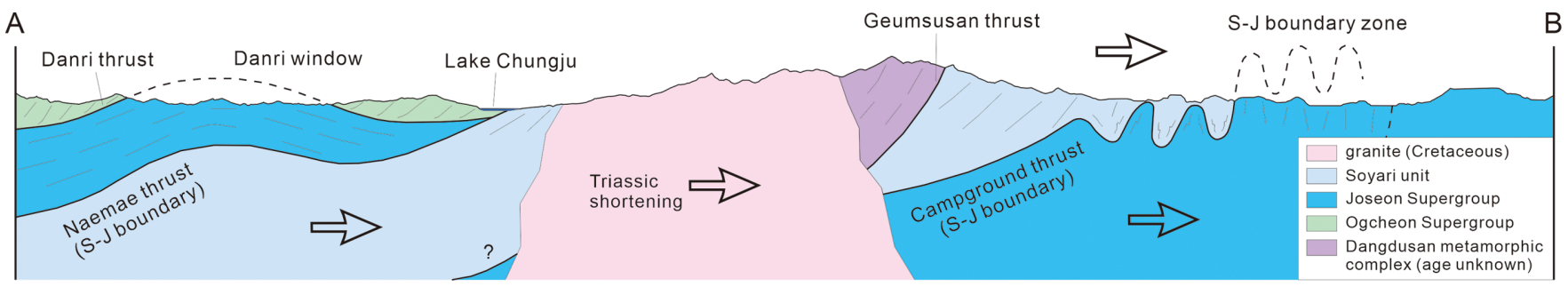

Figure 11. Schematic cross section of the study area (line A-B in Figure 1). The Geumsusan thrust after Kihm and Kim (2003).
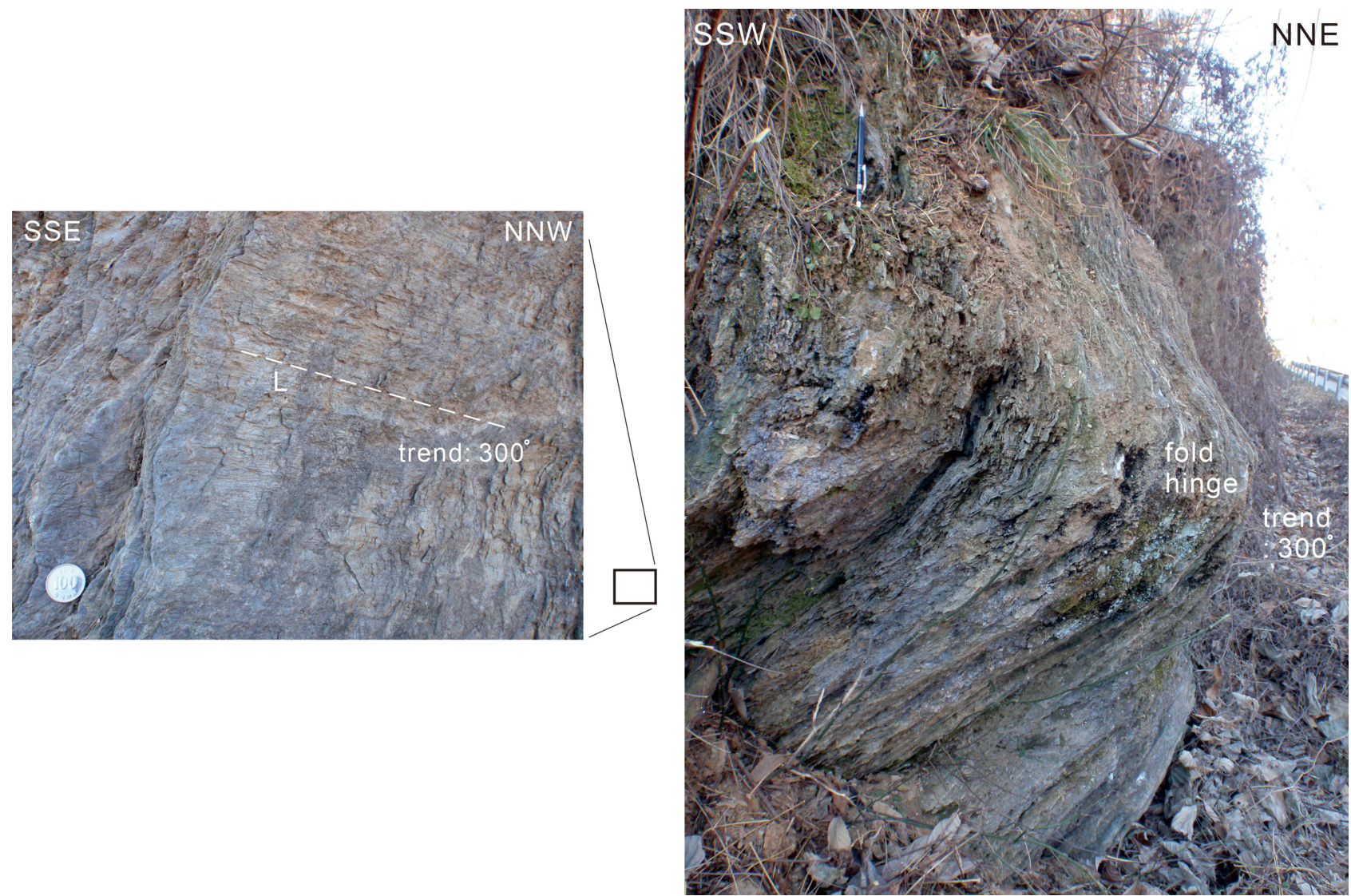

Figure 12. Minor folds (right) and crenulation lineation (L) associated with the map-scale upright folds (see Fig. 10). The crenulation lineation and fold hinge show the same trend $\left(300^{\circ}\right)$ and plunge $N W$ at low angle. The fold and crenulation lineation nearly coincide with the mapscale folds in trend. The coin is $2.4 \mathrm{~cm}$ in diameter. The pencil is $14 \mathrm{~cm}$ long. A roadcut $\sim 2.3 \mathrm{~km} \mathrm{ENE} \mathrm{of} \mathrm{gss} \mathrm{5-2} \mathrm{in} \mathrm{Fig.} 10$.

outcrop- to map-scale folds mostly trend NW (Figs. 10, 12, and 13b). Such remarkable consistency in structural trend (NNW to NW) is one peculiar feature of the boundary zone between the Ogcheon metamorphic belt and the Taebaeksan Basin, clearly distinguished from that of surrounding regions (NE or N). We suppose that the rock units and pre-existing structures occurring east of Lake Chungju were subject to a vertical-axis rotation by strong NE- or ENE-directed shortening. It is also likely that the decollements (Danri and Naemae thrusts) existing from Lake Chungju to the west and outcrop- to map-scale folds occurring east of the lake formed due to such NE- or ENE-directed shortening.

The NW- to NNW-trending structures and rock units in our area and in an area neighboring to the east (Danyang) involve the Paleozoic sequences of Joseon and Pyeongan Supergroups as well as the Soyari unit (Hwang et al., 1996; Kim, 1996; Koh et al., 2001; this study). The
Joseon and Pyeongan Supergroup sequences are unconformably overlain by the Jurassic Bansong Group sequences which do not contain such NW- to NNW-trending structures (Kim and Koh, 1992; Kim, 1996; Han et al., 2006). This suggests that the NW- to NNW-trending structures formed after termination of the Pyeongan Supergroup deposition at the late Permian or Early Triassic (Lee and Chough, 2006; Kim and Lee, 2017), but prior to opening of the Bansong basin at the Early Jurassic. We propose that the major thrusts (Danri, Naemae, Campground) and hence the decollements as well as other NW- to NNWtrending structures in the Jecheon-Maepo areas resulted from the NEor ENE-directed shortening during the Triassic Songrim Orogeny (Indosinian) (Fig. 14). Other authors also documented the NE-SW shortening in Danyang and our area, and suggested that the shortening was related with the Songrim Orogeny (Kim, 1996; Kihm and Kim, 2003). 
(a)

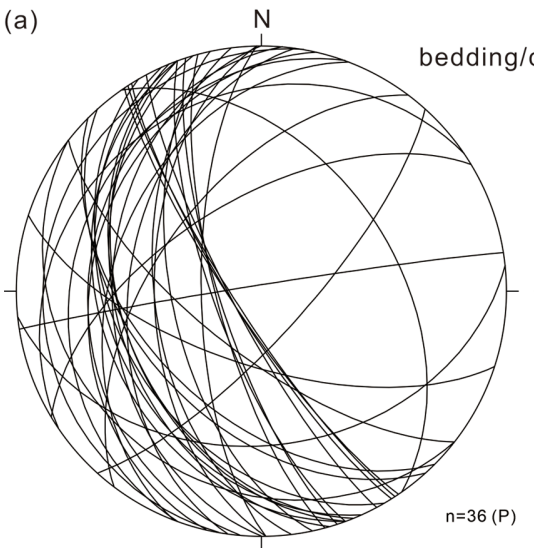

west of the S-J boundary zone
$\mathrm{N}$

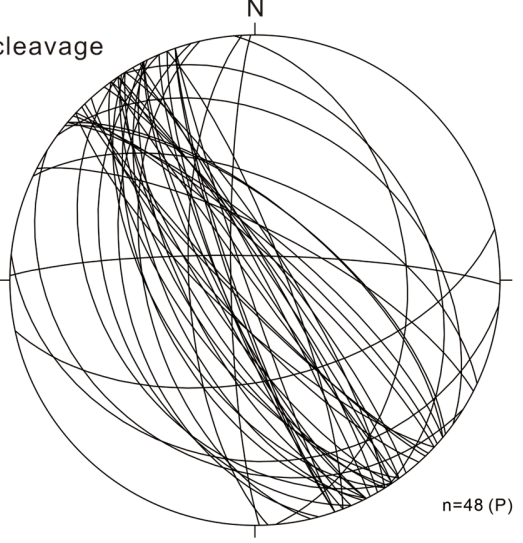

S-J boundary zone and vicinity

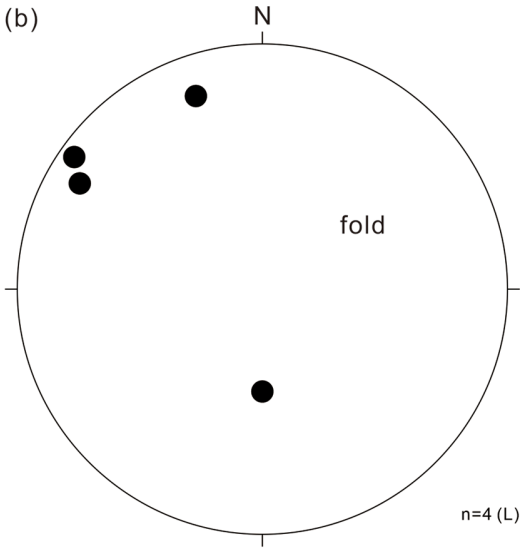

within and west of the S-J boundary zone

Figure 13. Stereograms showing orientations of (a) bedding/cleavage and (b) fold (crenulation lineation and outcrop-scale fold) in the Maepo area and vicinity. Lower hemisphere, equal area projection.

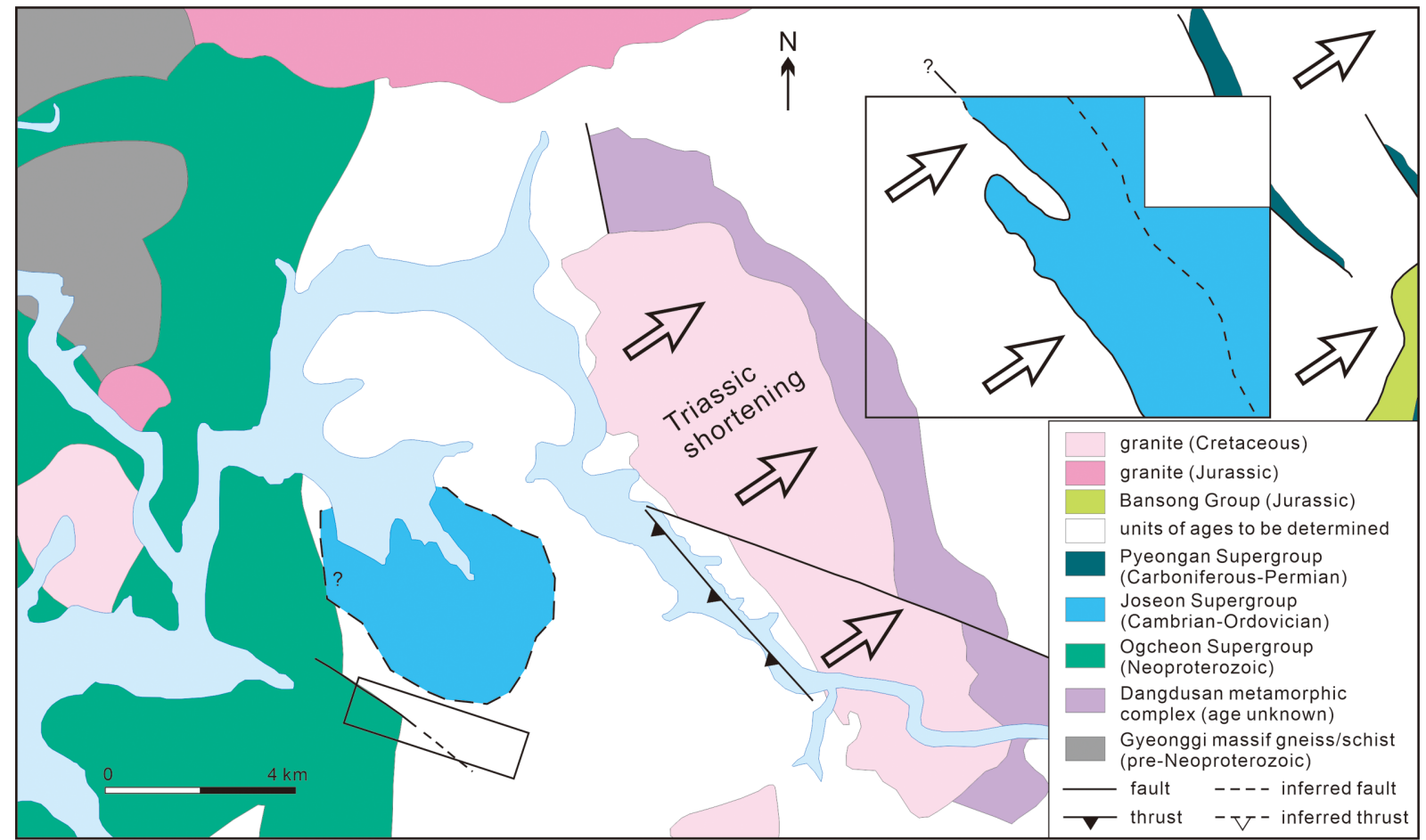

Figure 14. Map showing shortening direction (arrow) during the Triassic Songrim Orogeny (Indosinian). This shortening was predominant from Lake Chungiu to the east.

\section{Two Models for the Taebaeksan Basin-Ogcheon Meta- morphic Belt Relationship}

The boundary between the Taebaeksan Basin and the Ogcheon metamorphic belt has been viewed differently depending on tectonic models. Although the boundary itself has long been misunderstood in terms of its width and involved rock units, the boundary should be either a local structure (Kim et al., 2001; Lee and Lee, 2003; Oh and Kusky, 2007) or a continental transform fault (Chough et al., 2000; Ree et al., 2001; Choi, 2019b). We consider two alternative models for the origin of the Taebaeksan Basin and the Ogcheon metamorphic belt which dictates structural relationship between those two domains; (1) one plate model and (2) two plate model corresponding to above two views, respectively.

In the one plate model, the Taebaeksan Basin had formed close to the basin where the Ogcheon metamorphic belt evolved, and subsequently, the Ogcheon metamorphic belt was thrust onto the Taebaeksan Basin due to the NE- or ENE-directed shortening during the Triassic Songrim Orogeny (Fig. 15a). This is in line with Oh and Kusky's (2007) model suggesting presence of a collision zone between the North and South China Blocks within the Gyeonggi massif based on evidences for high-pressure or high-temperature metamorphism during the Triassic. In their model, the Gyeonggi/Yeongnam massifs, the Taebaeksan Basin, and the Ogcheon metamorphic belt were all considered as parts of the South China Block. On the other hand, some workers believed that the collision zone between North and South China Blocks does 
(a) One plate model

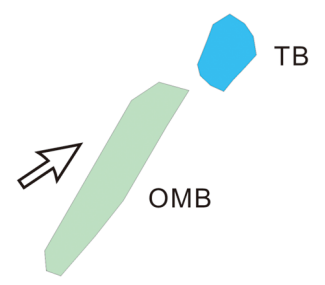

1. NE-directed shortening of the OMB

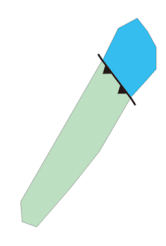

2. Welding of the $\mathrm{OMB}$ with the TB

(b) Two plate model

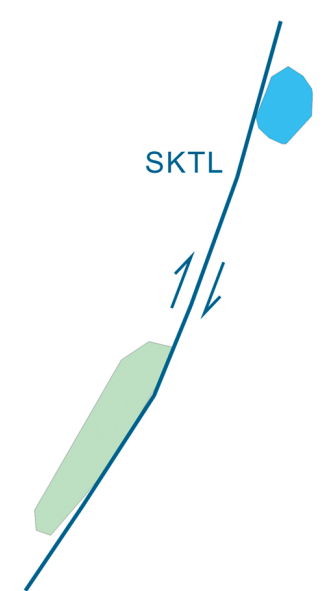

1. Southward migration of the TB along the SKTL

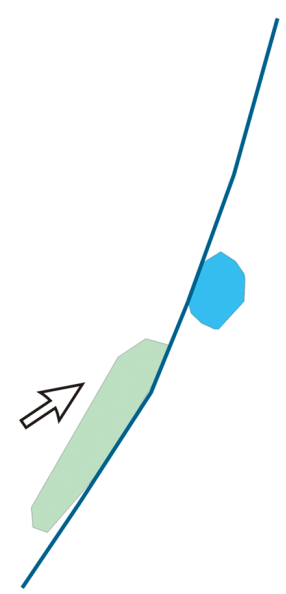

2. Onset of NE-directed shortening of the OMB

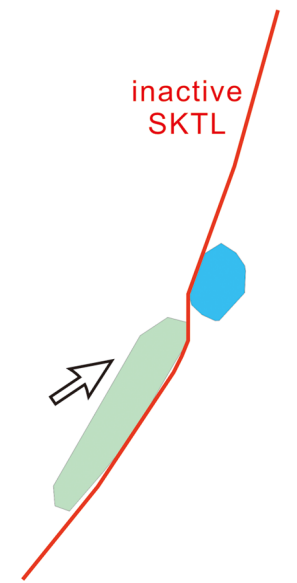

3. Cessation of the motion along the SKTL which began to bend

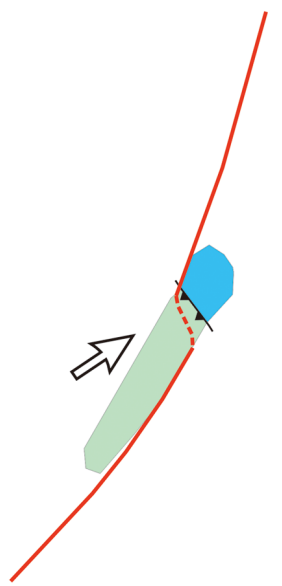

4. Structural burial of the SKTL beneath the thrust slices. and welding of the OMB with the TB

Figure 15. Two alternative models on how the Ogcheon metamorphic belt (OMB) and the Taebaeksan Basin (TB) formed. The dashed line is structurally-buried segment of the SKTL. SKTL: South Korean Tectonic Line.

not pass through Korea, and that whole Korean Peninsula constitutes a part of the North China Block (Kim et al., 2001; Lee and Lee, 2003). In all above models, no terrane boundary exists between the Taebaeksan Basin and the Ogcheon metamorphic belt. This is supported by our observation in the area east of Lake Chungju where no major strike-slip fault has been found between the Ogcheon metamorphic belt (Yamisan unit) and the Taebaeksan Basin (Joseon Supergroup) (Figs. 1 and 10; Lim and Choi, unpubl. data).

In the two plate model, the Taebaeksan Basin had belonged to the North China Block, and migrated hundreds kilometers southward along a continental transform fault to be welded to the Ogcheon metamorphic belt by the NE- or ENE-directed shortening during the Triassic Songrim Orogeny (Fig. 15b). This model is supported by following data sets. The trilobite faunal assemblages and age spectra of detrital zircons as well as stratigraphy of the Paleozoic sequences in the Taebaeksan Basin are very similar to those of the North China Block (Kim et al., 2001; Lee and Lee, 2003; Choi, 2009, 2019a). It has been suggested that the Ogcheon metamorphic belt resulted from an early Permian orogeny of intracontinental nature, the Ogcheon orogeny (Cho and Kim, 2002, 2005; Cheong et al., 2003; Kim et al., 2007). In the Taebaeksan Basin, however, sedimentation continued until the late Permian or possibly the Middle Triassic (Lee and Chough, 2006; Kim and Lee, 2017). This suggests that the Taebaeksan Basin was apart from the Ogcheon metamorphic belt at a distance not affected by the Ogc- heon orogeny at least until the early Permian.

The South Korean Tectonic Line (SKTL) has been hypothesized as a continental transform fault that the Taebaeksan Basin-Yeongnam massif (North China affinity) and the Ogcheon metamorphic beltGyeonggi massif (South China affinity) were accreted during the Triassic Indosinian orogeny (Chough et al., 2000). Chough et al. (2000) explained that the accretion was a consequence of thrusting associated with strike-slip movement. However, the NE- or ENE-directed shortening which caused the accretion probably was a regional event unrelated to the transform faulting. This is because the ENE-directed shortening during the Songrim Orogeny was also documented in the western Gyeonggi massif (Lim, manuscript in prep.).

Our results do not rule out existence of the transform fault. The Soyari unit not belonging to the Ogcheon metamorphic belt nor the Taebaeksan Basin could be an exotic fragment and, therefore, supports existence of the inter-plate boundary. In the Jecheon-Maepo areas, the westernmost exposure of Joseon Supergroup unit through the Danri window suggests a possibility that the continental transform fault exists somewhere farther west beneath the thrust slice(s) (red, dashed line in Fig. 15b). In other words, the terrane boundary (SKTL) may have been effectively buried by low-angle thrusting during the Songrim Orogeny (Indosinian). This may be the reason why the SKTL has not been easily located on the surface. To trace the SKTL, the possibility of structural burial must be considered. 


\section{Conclusions}

In the Bonghwajae section, the "Yamisan unit" is suggested to be a part of the Neoproterozoic Ogcheon Supergroup based on occurrence of metavolcanic rock and its age $(761 \pm 3 \mathrm{Ma})$. In the Jecheon-Maepo areas, the "Soyari unit" of uncertain affinity is a metasedimentarymetavolcanic sequence deposited after the Cambrian. The metacarbonate rocks of Soyari unit can be distinguished from the carbonate rocks of Joseon Supergroup based on field criteria. Our results show that the boundary between the Taebaeksan Basin and the Ogcheon metamorphic belt in the Jecheon-Maepo areas (O-J boundary zone) is not a single contact but a more than $20 \mathrm{~km}$ wide zone where sequences of the Yamisan unit enclosing the "Danri window", the Soyari unit and the Joseon Supergroup are exposed.

We suggest that, in the Jecheon-Maepo areas, the Ogcheon Supergroup sequence overlies the Joseon Supergroup unit along a decollement (Danri thrust) based on occurrence of the Danri window. The Danri thrust and Naemae thrust existing from Lake Chungju to the west and other NW- to NNW-trending structures, predominant to the east of Lake Chungju, are suggested to have resulted from intense NE- or ENE-directed shortening which occurred during the Triassic Songrim Orogeny (Indosinian).

We suggest two alternative models for the origin/structural relationship of the Taebaeksan Basin and the Ogcheon metamorphic belt. In one plate model, the Taebaeksan Basin had formed close to the Ogcheon metamorphic belt and was emplaced beneath it by the NE- or ENE-directed shortening during the Songrim Orogeny. In two plate model, the Taebaeksan Basin had formed in the North China Block, and was transported hundreds kilometers southward along a transform fault. The Taebaeksan Basin was subsequently welded to the Ogcheon metamorphic belt by the NE- or ENE-directed shortening during the Songrim Orogeny. No major strike-slip fault to the east of Lake Chungju is consistent with the one plate model. However, existence of the Joseon Supergroup unit beneath the Ogcheon Supergroup sequence to the west of Lake Chungju still leaves the possibility open that the transform fault exists somewhere farther west, buried beneath thrust slice(s). The two plate model is a possibility, and therefore, the hypothesis of South Korean Tectonic Line (SKTL) is viable.

\section{Acknowledgements}

We thank two anonymous reviewers for their critical comments which substantially improved the manuscript. We also thank JinYong Lee for the editorial work. We appreciate permission of Kaushik Das and Hiroshi Hidaka in Hiroshima University to use their facility. We are grateful to Xiaohan Wang and Xinping Wang for many helps and discussions in managing geochronological data. Seung Hwan Lee and Byung Choon Lee are thanked for helps in dealing with geochemical data. Kenta Kawaguchi is thanked for help on petrographic work. We thank David Rowley for helpful comments on early version of this manuscript. This research was supported by NRF grant 2014R1A1A2002851, and NRF grant 2017K1A1A2013180.

\section{References}

Cheong, C.-S., Jeong, G.Y., Kim, H., Choi, M.-S., Lee, S.-H., and Cho, M., 2003, Early Permian peak metamorphism recorded in U-Pb system of black slates from the Ogcheon metamorphic belt, South Korea, and its tectonic implication. Chemical Geology, v. 193, pp. 81-92.

Cho, M., and Kim, H., 2002, Metamorphic evolution of the Ogcheon metamorphic belt: review of recent studies and remaining problems. The Journal of the Petrological Society of Korea, v. 11, pp. 121-137 (in Korean with English abstract).

Cho, M., and Kim, H., 2005, Metamorphic evolution of the Ogcheon belt, Korea: a review and new age constraints. International Geology Review, v. 47, pp. 41-57.

Choi, D.K., 1998a, The Yongwol Group (Cambrian-Ordovician) redefined: a proposal for the stratigraphic nomenclature of the Choson Supergroup. Geosciences Journal, v. 2, pp. 220-234.

Choi, D.K., 1998b, An Early Ordovician trilobite faunule from the Choson Supergroup, Maepo, Tanyang area, Korea. Geosciences Journal, v. 2, pp. 235-242.

Choi, D.K., 2009, Trilobite faunal assemblages of the Taebaeksan Basin and their importance in reconstructing the early Paleozoic paleogeography and paleoenvironments of Korean Peninsula. Journal of the Paleontological Society of Korea, v. 25, pp. 129-148 (in Korean with English abstract).

Choi, D.K., 2019a, Evolution of the Taebaeksan Basin, Korea: I, early Paleozoic sedimentation in an epeiric sea and break-up of the SinoKorean craton from Gondwana. Island Arc, 2019;28:e12275. doi: 10.1111/iar.12275

Choi D.K., 2019b, Evolution of the Taebaeksan Basin, Korea: II, late Paleozoic sedimentation in a retroarc foreland basin and assembly of the proto-Korean Peninsula. Island Arc, 2019;28:e12277. doi: 10.1111/ iar. 12277

Choi, D.K., Woo, J., and Park, T.-Y., 2012, The Okcheon Supergroup in the Lake Chungju area, Korea: Neoproterozoic volcanic and glaciogenic sedimentary successions in a rift basin. Geosciences Journal, v. 16, pp. 229-252.

Chough, S.K., Kwon, S.-T., Ree, J.-H., and Choi, D.K., 2000, Tectonic and sedimentary evolution of the Korean peninsula: a review and new view. Earth-Science Reviews, v. 52, pp. 175-235.

Cluzel, D., Jolivet, L., and Cadet, J.-P., 1991, Early middle Paleozoic intraplate orogeny in the Ogcheon belt (South Korea): a new insight on the Paleozoic buildup of east Asia. Tectonics, v. 10, pp. 1130-1151.

Coutts, D.S., Matthews, W.A., and Hubbard, S.M., 2019, Assessment of widely used methods to derive depositional ages from detrital zircon populations. Geoscience Frontiers, v. 10, pp. 1421-1435.

Hwang, J.-H., Kim, D.-H., Cho, D.-L., and Song, K.-Y., 1996, Andong Sheet. Korea Inst. Geol. Mining and Materials (KIGAM), Sheet NJ5214 , scale $1: 250,000$.

Han, R., Ree, J.-H., Cho, D.-L., Kwon, S.-T., and Armstrong, R., 2006, SHRIMP U-Pb zircon ages of pyroclastic rocks in the Bansong Group, Taebaeksan Basin, South Korea and their implication for the Mesozoic tectonics. Gondwana Research, v. 9, pp. 106-117.

Kihm, Y.H., Kim, J.H., and Koh, H.J., 1996, Geology of the Deogsan-myeon area, Jecheon-gun, Chungcheongbuk-do, Korea: contact between the Choseon and Ogcheon supergroups. Journal of the Geological Society of Korea, v. 32, pp. 483499 (in Korean with English abstract).

Kihm, Y.H., and Kim, J.H., 2003, Structural characteristics of the central Ogcheon belt, South Korea: orogen-parallel tectonic transport model. Journal of Asian Earth Sciences, v. 22, pp. 41-57.

Kim, H., Cheong, C.S., and Cho, M., 2007, The effect of allanite inclusions on $\mathrm{U}-\mathrm{Pb}$ step leaching ages and $\mathrm{Sm}-\mathrm{Nd}$ isotope systematics of garnet from the Ogcheon metamorphic belt, South Korea. Chemical Geology, v. 236, pp. 27-41. doi: 10.1016/j.chemgeo.2006.08.014

Kim, H.S., Ree, J.-H., and Yi, K., 2018, The tectonic boundary between 
the Okcheon and Taebaeksan basins, South Korea: A restraining bend of a continental transform fault between the South and North China Cratons. Island Arc, 2018;27:e12237. doi: 10.1111/iar.12237

Kim, J.H., 1996, Mesozoic tectonics in Korea. Journal of Southeast Asian Earth Sciences, v. 13, pp. 251-265.

Kim, J.H., and Koh, H.J., 1992, Structural analysis of the Danyang area, Danyang coalfield, Korea. Journal of the Korean Institute of Mining Geology, v. 25, pp. 61-73.

Kim, J.H., Lee, Y.I., Li, M., and Bai, Z., 2001, Comparison of the Ordovician-Carboniferous boundary between Korea and NE China: Implications for correlation and tectonic evolution. Gondwana Research, v. 4, pp. 39-53.

Kim, M.G., and Lee, Y.I., 2017, The stratigraphy and correlation of the upper Paleozoic Pyeongan Supergroup of southern Korean Peninsula A review. Journal of the Geological Society of Korea, v. 53, pp. 321-338 (in Korean with English abstract).

Kim, O.J., and Kim, K.H., 1974, The study of structure and petrology of the area between Susanri and Hwanggangri. Journal of the Korean Institute of Mining Geology, v. 7, pp. 101-122 (in Korean with English abstract).

Kim, S.W., Oh, C.W., Ryu, I.-C., Williams, I.S., Sajeev, K., Santosh, M., and Rajesh, V.J., 2006, Neoproterozoic bimodal volcanism in the Okcheon belt, South Korea, and its comparison with the Nanhua rift, south China: implications for rifting in Rodinia. Journal of Geology, v. 114, pp. 717-733.

Koh, H.J., Kim, J.C., Lee, S.R., Lee, C.-B., and Park, K.-H., 2001, Gangreung Sheet. Korea Inst. Geol. Mining and Materials (KIGAM), Sheet NJ52-10, scale 1:250,000.

Lee, H.S., and Chough, S.K., 2006, Lithostratigraphy and depositional environments of the Pyeongan Supergroup (Carboniferous-Permian) in the Taebaek area, mid-east Korea. Journal of Asian Earth Sciences, v. 26, pp. 339-352.

Lee, K.-S., Chang, H.-W., and Park, K.-H., 1998, Neoproterozoic bimodal volcanism in the central Ogcheon belt, Korea: age and tectonic implication. Precambrian Research, v. 89, pp. 47-57.
Lee, M.S., and Park, B.S., 1965, Geological map of Hwanggang-ni Sheet. Geol. Surv. Korea, Sheet 6824-IV, scale 1:50,000.

Lee, S.-B., 2020, Reconsideration on the invertebrate fossil fauna from Cheongpung-myeon, Jecheon City, Chungcheongbuk-do, Korea: a preliminary report. Journal of the Geological Society of Korea. v. 56, pp. 605617 (in Korean with English abstract).

Lee, Y.I., and Lee, J.I., 2003, Paleozoic sedimentation and tectonics in Korea: A review. Island Arc, v. 12, pp. 162-179.

Lim, S.-B., Chun, H.Y., Kim, Y.B., Kim, B.C., and Cho, D.-L., 2005, Geologic ages, stratigraphy and geological structures of the metasedimentary strata in Bibong-Yeonmu area, NW Okcheon belt, Korea. Journal of the Geological Society of Korea, v. 41, pp. 335-368 (in Korean with English abstract).

Oh, C.W., and Kusky, T.M., 2007, The Late Permian to Triassic HongseongOdesan collision belt in South Korea, and its tectonic correlation with China and Japan. International Geolology Review, v. 49, pp. 639-657.

Park, K.-H., Lee, T.-H., and Yi, K., 2011, SHRIMP U-Pb ages of detrital zircons in the Daehyangsan Quartzite of the Okcheon Metamorphic Belt, Korea. Journal of the Geological Society of Korea, v. 47, pp. 423-431 (in Korean).

Ree, J.-H., Kwon, S.-H., Park, Y., Kwon, S.-T., and Park, S.-H., 2001, Pretectonic and posttectonic emplacements of the granitoids in the south central Okchon belt, South Korea: implications for the timing of strikeslip shearing and thrusting. Tectonics, v. 20, pp. 850-867.

Reedman, A.J., Fletcher, C.J.N., Evans, R.B., Workman, D.R., Yoon, K.S., Rhyu, H.S., Jeong, S.W., and Park, J.N., 1973, The geology of the Hwanggangni mining district, Republic of Korea. Geol. Min. Inst. Korea, 118 p.

Sohn, J.W., and Choi, D.K., 2002, An uppermost Cambrian trilobite fauna from the Yongwol Group, Taebaeksan Basin, Korea. Ameghiniana, v. 39, pp. 59-76.

Son, C.M., 1970, On the geological age of the Ogcheon Group. Journal of the Korean Institute of Mining Geology, v. 3, pp. 915 (in Korean with English abstract).

Winter, J.D., 2010, Principles of Igneous and Metamorphic Petrology. New York, Prentice Hall, 702 p.

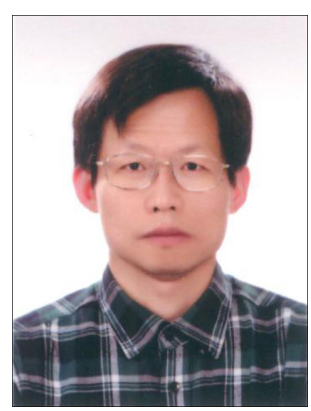

Chul Lim completed bachelor's degree (geology major) in 1989 at the Seoul National University, Korea. He earned master's degree (sedimentary petrology) at the same school in 1994. He obtained another master's degree (structural geology/regional tectonics) in 1998 at the Florida State University. He completed $\mathrm{Ph} . \mathrm{D}$. degree (structural geology/regional tectonics) in 2007 at the State University of New York (Albany). His Ph.D. study was primarily focused on deciphering crustal motions related to orogenic events in the northern Appalachians and the southeastern Tibet. He studied orogenic events in Korea and eastern China when he was a post-doctoral fellow or BK21 researcher in the Seoul National University for nearly 9 years. He continued the same research while he stayed over 2 years at the Jeonbuk National University as a post-doctoral fellow. He is interested in analyzing crustal motions accurately based on field mapping and kinematic analysis, which leads to reliable reconstruction of plate motions and paleogeography.

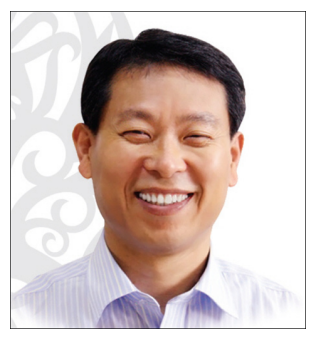

Chang Whan Oh is Professor of Department of Earth and Environmental Sciences, Jeonbuk National University, Korea. He was the president of the Petrological Society of Korea. Now he is working as Associate Editor of Geochemical Journal and Managing Guest Editor of Lithos special issue. Over the past three decades, he has been mainly working on the Permo-Triassic collision belt in the Korean Peninsula, the geological correlation between Korean Peninsula and China from Paleoproterozoic to Cretaceous time, and tectonic model of Qinling-Dabie-Sulu-HongseongOdesan collision belt based on the metamorphic and igneous studies. His greatest achievement is the discovery of eclogite, evidence for Permo-Triassic continental collision in the Korean Peninsula. 


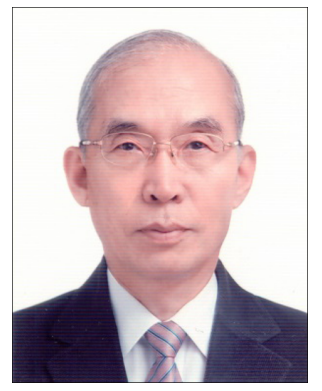

Duck K. Choi is Professor Emeritus of School of Earth and Environmental Sciences, Seoul National University, Korea. He was the president of the Paleontological Society of Korea and was a voting member of the International Subcommission on Cambrian Stratigraphy. Over the past three decades, he has been mainly working on the Cambrian-Ordovician trilobites of the Taebaeksan Basin, Korea, and based on the paleontological information, he has been deeply involved in stabilizing the lower Paleozoic stratigraphic nomenclature of the Taebaeksan Basin and in revealing the Paleozoic paleogeographic and tectonic evolution of the Korean Peninsula.

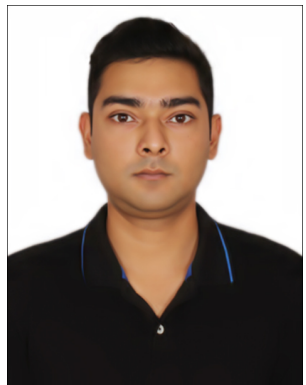

Amitava Chatterjee was a postdoctoral researcher at the Indian Institute of Technology Bombay (IITB), India. He completed PhD in Earth Science (specialization: Metamorphic Petrology and Geochronology) from Hiroshima University, Japan in September 2017. During his $\mathrm{PhD}$, he carried out zircon U-Pb SHRIMP and monazite U-Th-total $\mathrm{Pb}$ EPMA dating along with meso- to microtextural analysis and thermodynamic modelling to understand the spatiotemporal geological evolution across a Precambrian orogen-craton boundary (Eastern Ghats Granulite Belt-Bastar craton) during the Grenvillian and Pan-African orogeny. His extensive knowledge in geochronology and metamorphic petrology was utilized during his postdoctoral research in the Department of Earth and Environmental Sciences, Jeonbuk National University, South Korea. He is vastly experienced in handling a SHRIMP (for U-Pb dating) and EPMA (for mineral chemistry and U-Th-total dating) to constrain different stages of metamorphism with time. $\mathrm{He}$ is currently working as a Research Associate at the Wadia Institute of Himalayan Geology, India to understand the high-grade metamorphic evolution of the Sikkim Higher Himalaya with time.

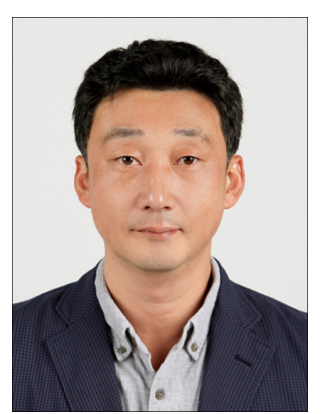

Youn-Joong Jeong is I am Ph.D. in Mineral \& Energy Resource Engineering at Chosun University in Korea. I currently works at the Earth and Environmental Analysis Team, Korea Basic Science Institute. I research in Isotope geochemistry, Geochronology and the provenance of artifacts. 